\title{
The Great Bull Markets 1924-29 and 1982-87: Speculative Bubbles or Economic Fundamentals?
}

\author{
G. J. Santoni
}

Every so often, it seems, humankind almost en masse has a compulsion to speculate, and it yields to that compulsion with abandon.

- Robert T. Patterson, The Greal Boom and Panic, p. xií.

$\mathbf{M}$ the subsequent collapse in stock prices to a "speculative bubble." According to this view, the crash was inevitable because it was only a matter of time until the bubble burst isee shaded insert on opposite pagel.

The same theory of stock price formation is used to describe the bull market of $1982-87$. Recent discussions have characterized this bull market as the product of "unexpected insanity," subject to "trading fads and frenzies rather than economic fundamentats" and "out of control." Comparisons between the 1920 s and 1980s like the one summarzed in chart 1 have appeared recently in the press." Chart 1 , which plots quarterly data on the levels of the Dow Jones Indus-

G. U. Santoni is a senior economist at the Feoteral Reserve Bank of St Louis. Thomas A. Pollmann provided research assistance.

'See the shaded insert on page and Kindleberger (1978), p. 17.

2"Abreast of the Market" (1987) and Jonas and Farrell (1986).

'See, for example, Koepp (1987). Powell (1987). Schwartz and Tsiantar (1987) and Walf Streef Joumal (1987). trial Index over the two periods, shows that the behav ior of stock prices in both periods is similar.' Both bull markets began in the second quarter of the year; each lasted 21 quarters; each hit its peak in the third quarter with the timing of the peaks separated by only a few days (September 3, 1929, and August 25, 1987); in each case, 54 days elapsed between the peak and the crash; and each crash stripped slightly more than 20 percent from the stock market averages.

The belief that speculative bubbles might cause a persistent deviation in stock prices from the price consistent with the fundamentals is important. At the time of the 1929 crash, it spawned legislative proposals that would curb credit for speculation, amend the National Banking and Federal Reserve acts, impose an excise tax on stock sales and regulate the activities of stock exchanges and investment trusts." Furthermore,

${ }^{4}$ Scale $(1982-67)=8 \times$ scale $(1924-29)$.

sNew York Times (October 25, 1929). 


\section{Some Popular Notions Regarding the Cause of the 1929 Grash}

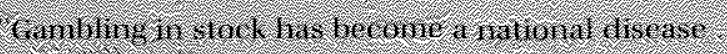

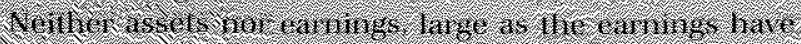

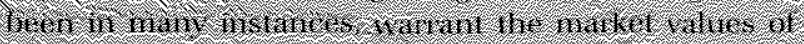

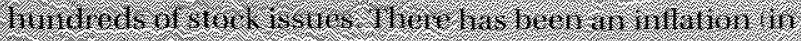

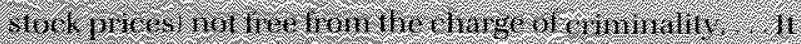

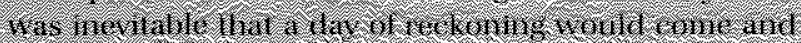

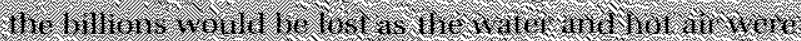

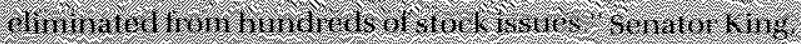

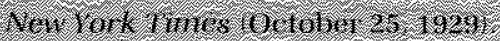

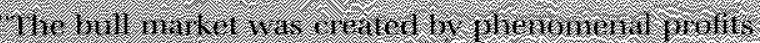

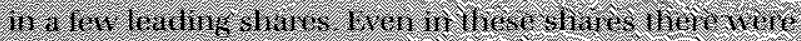

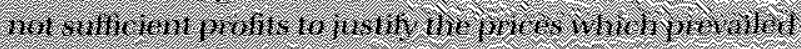

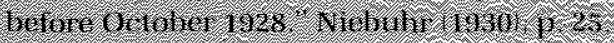

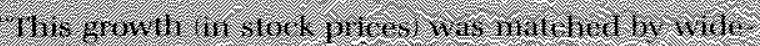

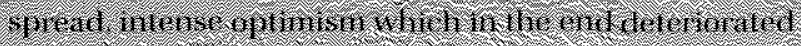

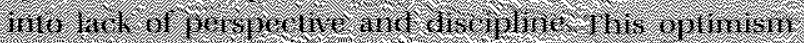

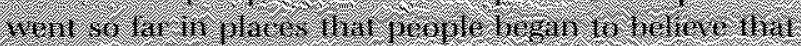

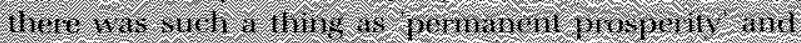

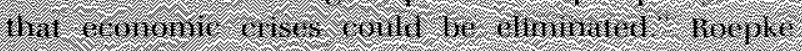
19.

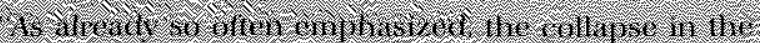

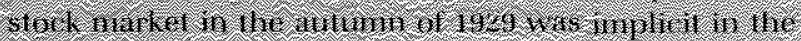

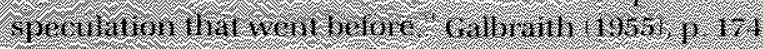

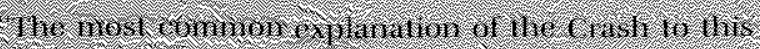

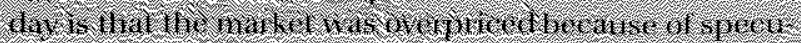

Win:

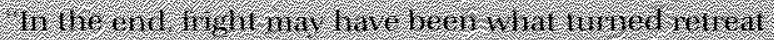

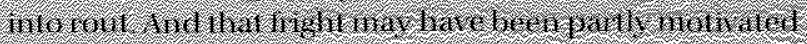

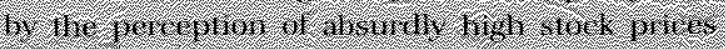

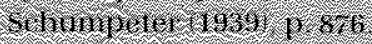

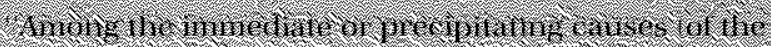

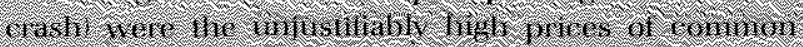

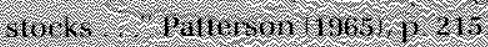

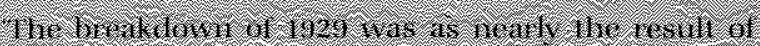

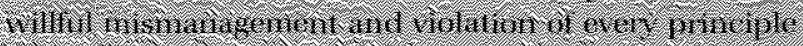

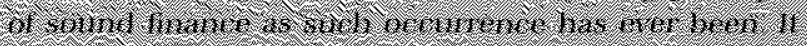

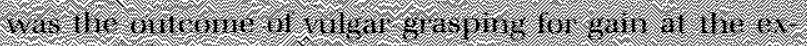

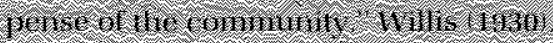

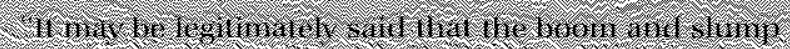

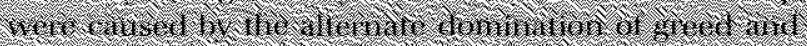

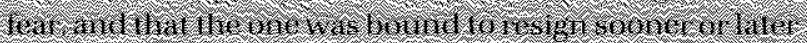

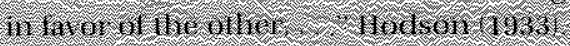

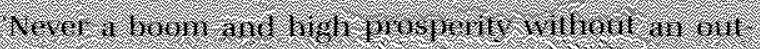

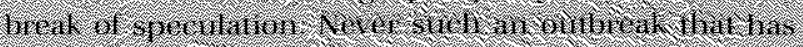

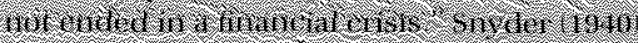

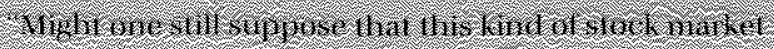

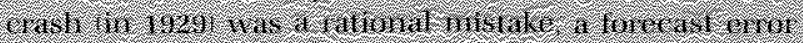

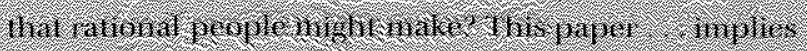

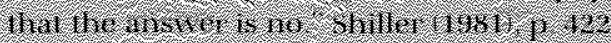

if stock price bubbles exist, economic policymakers face a difficult problem because bubbles suggest that plans to save and invest may be based on imrational criteria and subject to erratic change tr

The purpose of this paper is to compare the implications of a theory of stock prices based on fundamentals to one that allows for bubbles, then to examine

KKeynes (1935), p. 159. Keyres discussed erratic shifts in the investment schedule caused by changes in the "state of confidence" (pp. $153-55)$ and "speculation" (p. 161$)$. He argues that a

\begin{abstract}
". . . boom which is destined to end in a slump is caused. therefore, by the combination of a rate of interest, which in a correct state of expectation would be too high for full employment. with a misguided state of expectation which, so long as it tasts, prevents this rate of interest from being in fact deterrent. A boom is a situation in which over-optimism triumphs over a rate of interest which, th a cooler light, would be seen to be excessive (p. 322).
\end{abstract}

See, as well, Gordon (1952), p. 378 and Varian (1979). evidence from the 1920 s and the 1980 s to determine which set of implications is supported by the data. The behavior of stock prices during these two periods is particulary useful in tessing asset prices for the presence of speculative bubbles. The 1924-29 experience is one of the most significant bull markets in US. history in both its duration and rate of advance. Though not quite as dramatic the behavior of stock prices in the 1980 s has been similar. If stock price bubbles exist, these are likely places to look for them.

\section{TIE FUNDAMENTALS OF STOCK PRTCES}

People wilue common stocks for their expected retum. Since investor's may choose among broad categories of stock the expected retum on any particular slock nust be equal to the expected retum on ofher 
Chart 1

The Bull Markets of the 1920s and 1980s $L$ Dow Jones Industrial Index (Nominal Values)

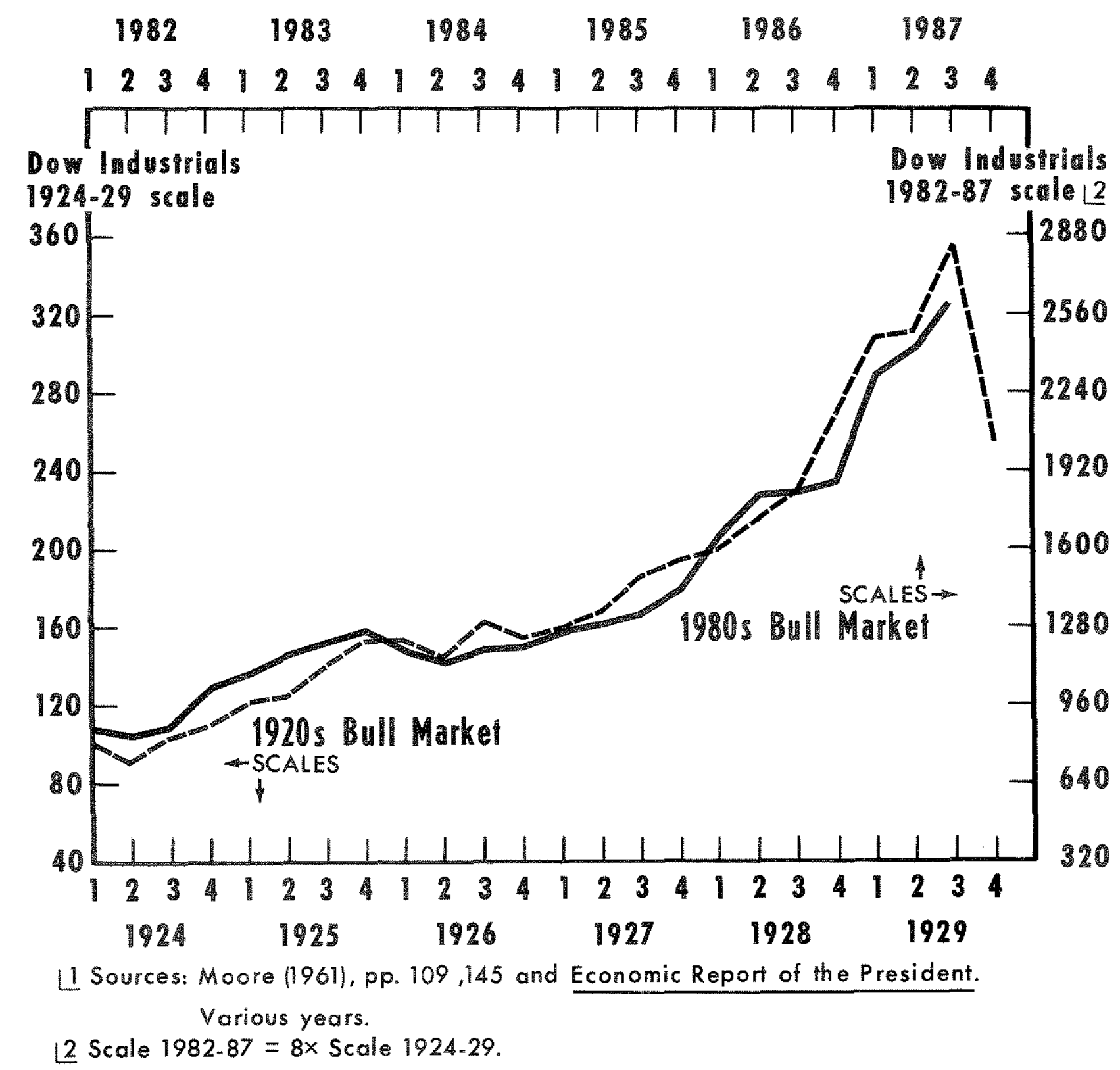


stocks of similar risk. For example, if a particular stock is expected to yield a relatively low retum, investors will shun it causing its price to fall. This raises its expected return. The reverse holds for any stock with an expected return that is higher than other stocks of similar risk. An equilibrium exists when the expected returns are equal across equally risky stocks. Economists call this equilbrium return the required discount rate. Equation 1 calculates the expected return from holding a stock for one year assuming dividends are paid at year-end. ${ }^{7}$

(1) Expected Rate of Return =

Forecast of price at year end + Forecast of dividend-Current Price

\section{Cument Price}

Equation 2 solves equation 1 for the current price by noting that the expected return is equal to the re quired discount rate in equilibrium.

(2) Current Price =

Forecast of price at year-end + Forecast of dividend

$(1+$ Required discount rate)

\section{The Price Depends on Forecasts of Future Outcomes}

The important thing to note in equation 2 is that the current price depends on forecasts of future outcomes which, of course, are subject to change as new information becomes available. The price does not depend on dividends that are observed in the present as Senator King and others have implied in their comments on the behavior of stock prices during the 1920s (see shaded insert on page 17 ). The current price may change even though observed dividends do not and conversely.

\section{How Far Ahead?}

The discussion so far indicates that investors must forecast the price of the stock next period. What are the fundamentals for this future price? In principle, the future price depends on the stream of dividends and the required discount rate investors expect to prevail over the life of the firm. Typically this requires forecasts that extend into the distant future and suggests that the job of analyaing stock prices is formi-

${ }^{7}$ See Brealey (1983), pp. 67-72, and Brealey and Meyers (1984), pp. $43-58$. dable. It is sometimes possible to simplify the calculation, however. If dividerds are expected to grow at a constant annum rate and he discoun rate is constant, the calculation can be simplified as shown in equation 3.

(3) Current Price $=$

Forecast of dividond

Required discount rate - Fxpected growth rate of dividends

\section{The Price Fundamentals}

Restating the solution for the current price as in equation 3 is particularly useful for the purposes of this paper. Equation 3 is a list of the price fundamentals: the forecast of the dividend next period, the required discount rate, and the expected (forecast) growth rate of dividends. The solztion for the current price in equation 3 is called the fundamentas price. Furthemore, the equation can be used to show how relatively small changes in forecasts can account for relatively large changes in the fundamentals ptice. For example, suppose investors forecast a yeamend divdend of $\$ .60$ per share, an annual dividend growth rate of 6 percent and the required discount rate is 8 percent. Equation 3 indicates that the fundamentals price is 830 per share $[-.6 /(08-.06])$. Now suppose that new information leads investors to lower the forecast of dividend growth to 5 percent. This is a decine of about 17 percent in expected growth [ $=1.01 / .06 / 100]$. The fundamentals price, however, declines to $\$ 20$ $[=.6 / .08-.051]$, or more than 30 percent. Notice that a large dechine in price may occur even though observed dividend payments do not change, it is even possible for the price to decline when observed dividends rise.

\section{STOCK PRICES AND MEASURES OF TIE FUNDAMENTALS}

Table 1 shows annual average growth rates of the Dow Jones Industrial Index in each year during the fwo bull markets." The index rose rapidly during the

\footnotetext{
Brealey (1983), p. 69 . The current price is defined by equation 3 only if the expected growh rate in cividands is less than the required discount rate.

The date on stock prices used in this paper are daly closing levels of the Dow Jones indusirial Index. Daily closing levels of this index are available on a consistent basis from January 1915. See Pierce (1982). When possble, the siatistical results obtaned with his data were checked against results using daly closing levels of the Standard and Poor's Composite index. in no case were any qualitative differences observed.
} 


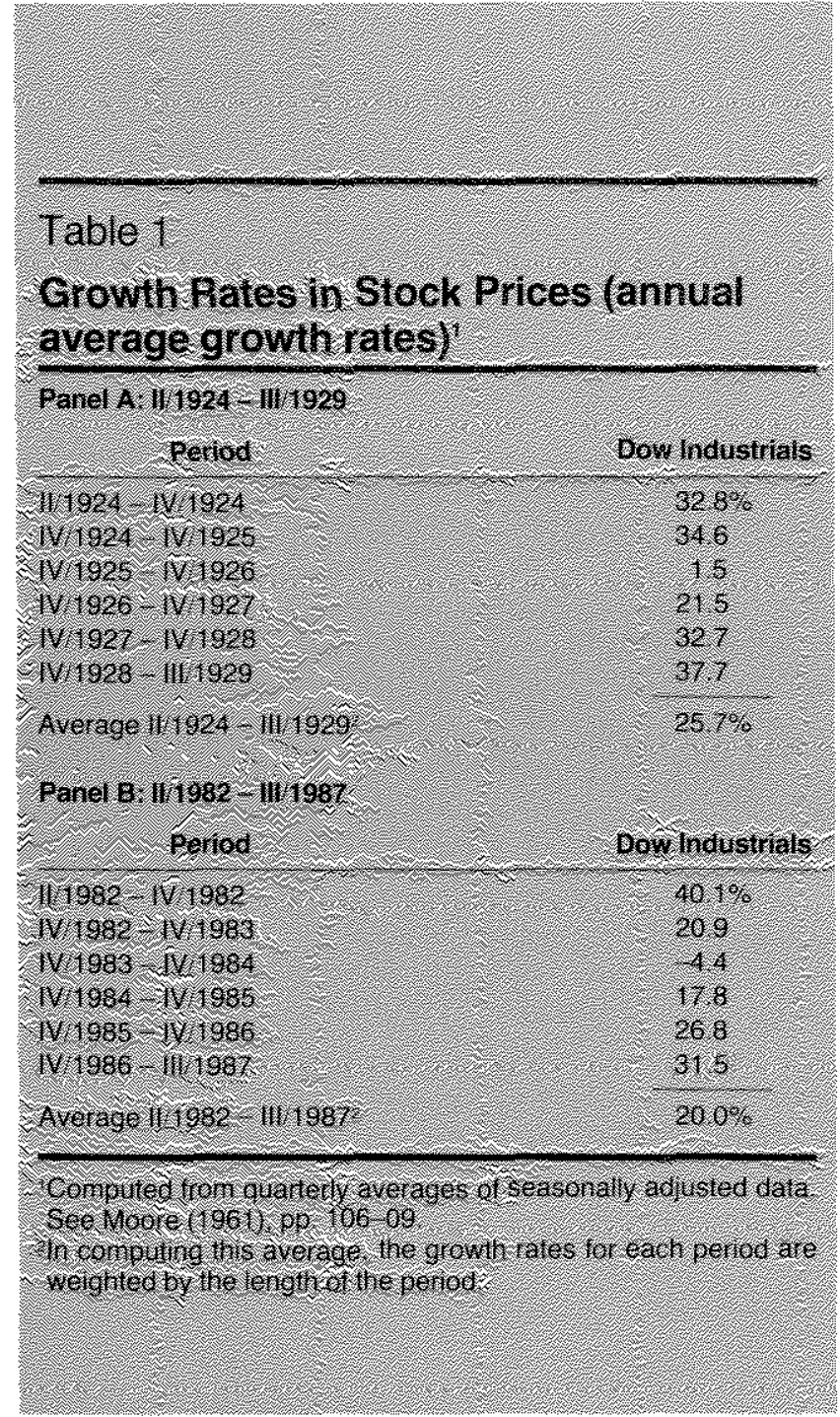

intial phases of the bull makets, slowed down considerably in 1926 and 1984 , hen rose mapidy through the third quarters of 1929 and $198 \%$.

A rapid advance in stock prices is not surprising if it tesults from dhanges in the furdamentals. The investgator, however, seldom has the luxury of direct observation of the fundamentals. Instead, other variables proxies that are believed to provide information about the behavior of the unobserved fundanentals must be used. For example, credit market interesi rates and actual divichd payments have been used to proxy the required discount rate and the expected stream of future dividends. It is important lo recognize What, at bes? the bethavior of these lor other! proxies may give only a rough approximation of the behavior of the hudamentals and on occasion, they may be enfively misleading. The 1920 s ma be an example of the latter case.
Long-term mates were roughly constant from 1924 29." Data on actual per share dividends are very sketchy for this period. One estmate, however, indicates that actual dividends increased at an annual rate of about 8.8 percent from $1924-29 .^{\prime \prime}$ While this is a farly rapid rate of increase, it is far less than the growth observed in stock values. ISee shaded insert on opposite page for a more precise estimate of the relationship between stock prices and these proxy vari ables. When the market crashed, people like Senator King pointed to these proxy varables and claimed that stock prices before October 1929 contamed "water and hot air." An attematve explanation is that the proxies give a misleading impression of the behavior of the fundamentals.

\section{FUNDAMENTALS, FOOLS AND BUBBLES}

In order to evaluate the notion that stock prices in the 1920s and 1980 s were driven by psychological factors extraneous to the fundamentals, it is necessary to be clearer about the implications the altenative hypotheses have for variables that can be observed by the investigator. This paper considers three different theories that potentially explain stock prices: the efficient market hypothesis, the greater fool theory and the theory of rational bubbles.

\section{Efficient Markets and Fundamentals}

A long-standing proposition in both economics and finance is that stock prices are formed in efficient markets. This means that all of the relevant informafion currently known aboul interest rates, dividends and the future paspeets for fims is contained in current stock prices. Stock prices change only when new information regarding the fundamentals is obtained by someone. New information, by definition, annot be predicted ahead of its arival because the news is just as likely to be good as it is to be bar, jumps in stock prices cannot be predicted in advance.

Many present-day stock market analysts are skeptical of the efficient markets hypothesis. "Similarly,

\footnotetext{
10 See Friedman and Schwartz (1982), table 4.8, and Homer (1977), p. 352.

11 See Cowles (1938), p. 389.

${ }^{12}$ See Brealey and Meyers (1984), pp. 266-81; Malkiel (1981), pp. 171-79; Brealey (1983), pp. 15-18; Leroy (1982) and Fama (1970).

is See Malkiel (1981), pp. 126-79.
} 


\section{The Relationship Between Growth in Stock Prices, Dividends Per Share and the Interest Rate: $1872-1930$}

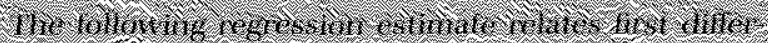

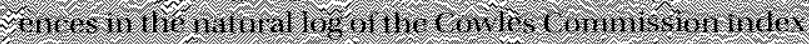

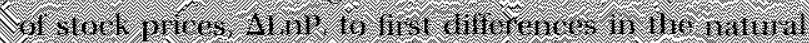

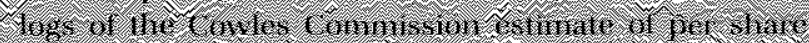

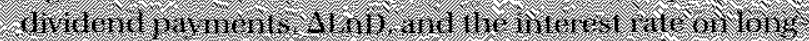

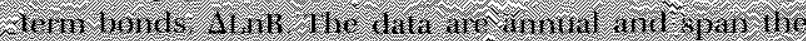

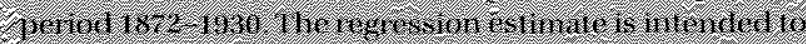

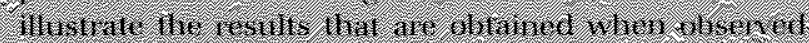

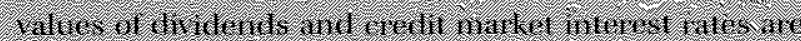

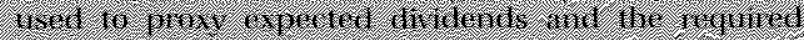

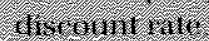

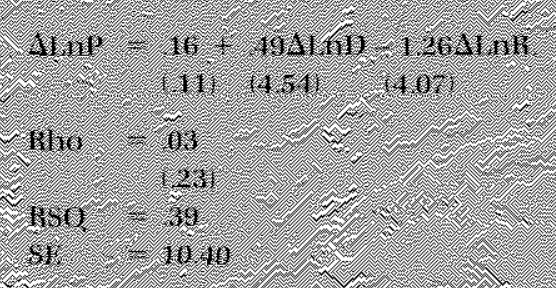

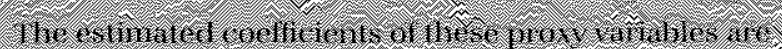

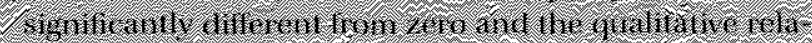

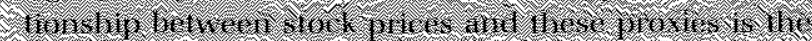

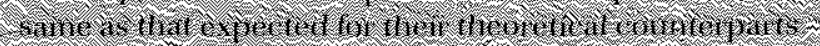

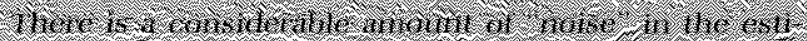

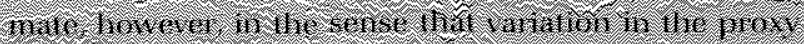

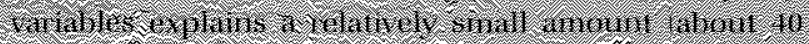

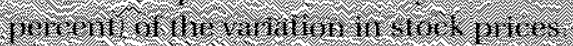

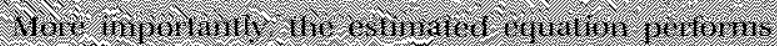

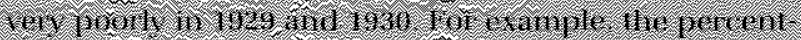

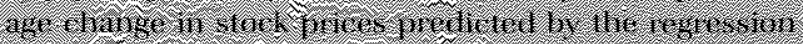

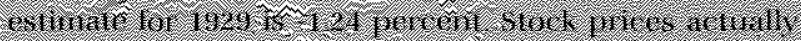

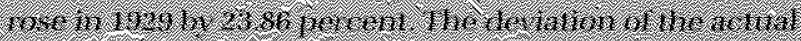

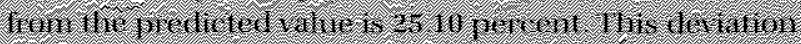

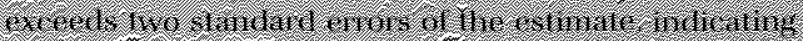

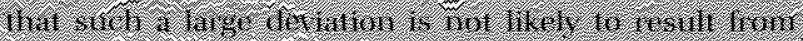

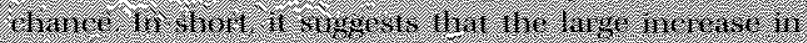

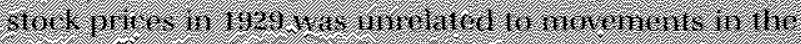

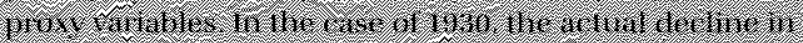

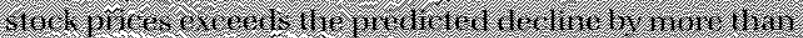

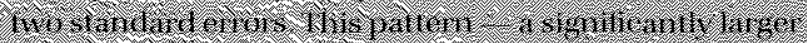

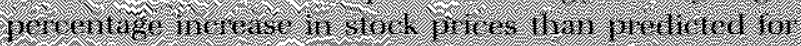

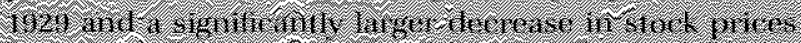

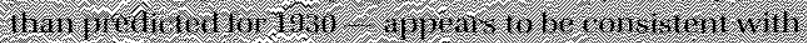

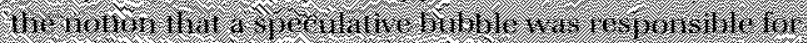

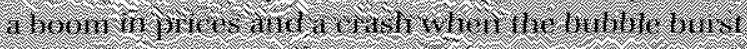

traders in the 1920 s generally did not subscribe to it (see shaded insert on following page). But that is not important. If the behavior of stock prices is consistent with the implications of the theory, the hypothesis helps both to understand how stock markets work and to evaluate the claim that the bull markets were products of price bubbles.

If the efficient markets hypothesis is correct, past price changes contain no useful information about future price changes. With some added assumptions, this can be translated into useful empirical propositions. If the expected return to holding stock is constant and the volatility of stock prices does not change duing the thme period examined the efficient maket hypothesis implies that observed changes in stock prices should be uncorrelated and that price changes should not exhibit long sequences of successive changes that are greater of less than the median change for the sample.
The above propositions should hold even if the level of stock prices appeass to drift upward or downward. These propositions concem the relationship between the sequence of price changes, not the average change over some specific period. Clearly, stock prices drifted upward during both bull markets; but that does not necessarily mean that price changes were correlated or that there were long runs of positive changes that exceeded the median change for these periods. Put diferently, it does not necessarily mean that market participants were able to predict future changes in stock prices by observing the past.

\section{Greater Fools}

The notion that self-feeding speculative bubbles, on occasion, can drive stock prices is known as the "greater fool theory." According to this theory, people regard the fundanenals as irelevant. Rather, they buy stock on the belief that some (bigger?) fool will buy 


\section{What Some Big Plungers Thought of Efficient Markets}

\section{Whiam C. Dimant}

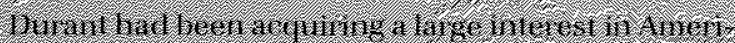

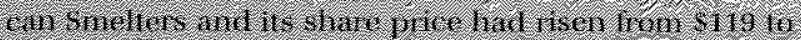

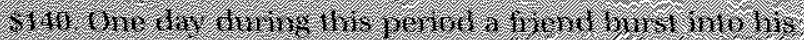

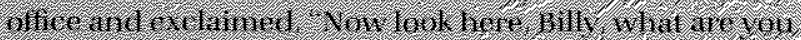

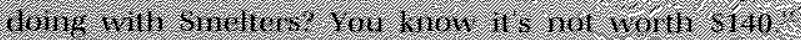

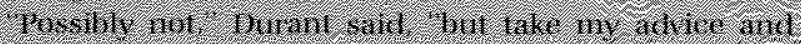

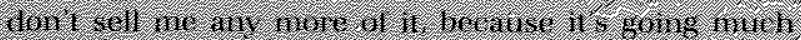

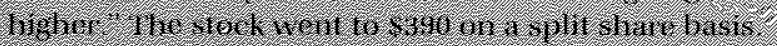

\section{Iesse Livermore}

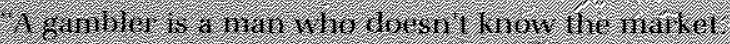

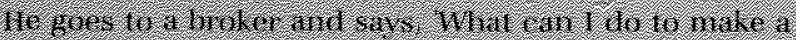

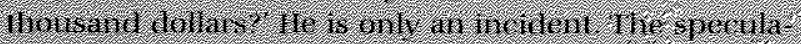

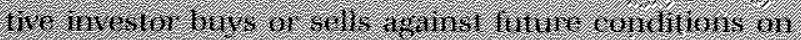

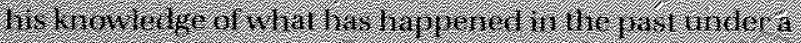

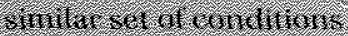

\section{Louis W. Uimmerman}

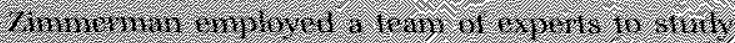

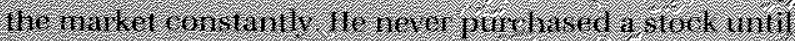

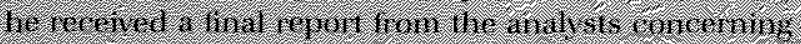

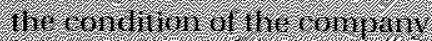

\section{Anhir W. Cuten}

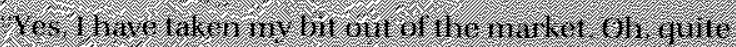

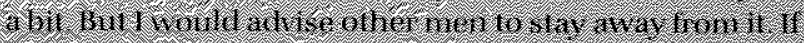

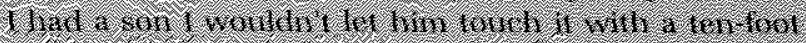
1010

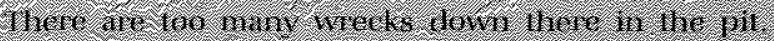

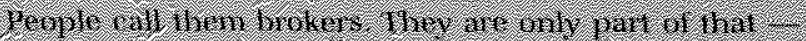

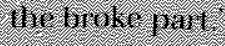

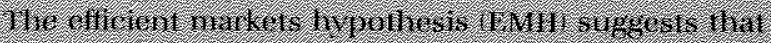

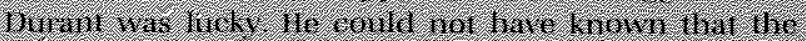

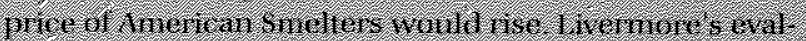

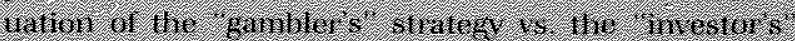

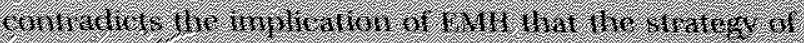

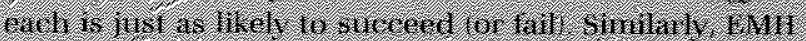

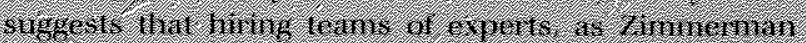

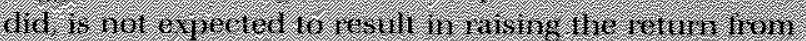

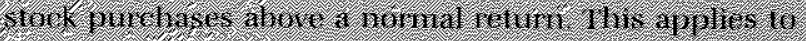

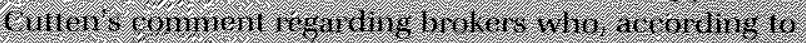

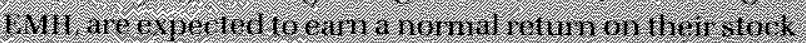

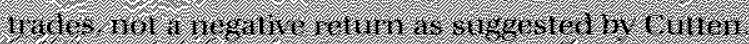

See spaning (1930), various pages. the shares from them at a higher price in the future. people maintain this belief because they think "that market values will rise - as they did yesterday or last week - and a protit can be made." Once the speculation begins, stock prices continue rising because people, seeing the rise in the previous period, demand additional shares in the belief that prices will continue to rise. This pushes prices still higher.

The greater fool theory is based on the presumption that there are times when past movenents in stock prices matter. According to this theory, during the "fooling" periods, there should be positive correlation in the past sequence of price changes and long runs of positive changes that exceed the median change for the sample period.

${ }^{14}$ Galbraith (1955), p. 23. See, as well, Malkiel (1981), pp. 31-49.

\section{Rational Bubbles}

Recently, some economists have discussed the possibility that stock prices may contain "rational" bubbles." The theory of rational price bubbles is based on the belief that some asset prices (for example, stock, gold and foreign currency prices) are too variable to be justified by variation in the fundamentals. ${ }^{16}$ A more formal theory of price bubbles is summarized in the appendix to this paper.) Briefly, the theory says that there may be occasions when stock prices deviate from the price that is consistent with the fundamentals. The deviation is called a bubble.

15See Flood and Garber (1980 and 1982), Blanchard and Watson (1982), West (1986), Diba and Grossman (1985 and 1986) and the appendix to the paper.

16See, for example, Shiller (1981) and Mankiw, Romer and Shapiro (1985). 
Bubbles must possess certain characteristics if they are to have economic significance:

Bubbles must be persistent so that a forecast of stock prices based solely on the fundamentals is biased. This means that forecast errors lactual price minus forecast price) will tend to have the same sign and not average out. The persistence of one-sided eaross is important because random variation in the data generally will cause the actual price to differ from any well-constructed forecast of the price even though a bubble is not present. If bubbles were only a name used to describe random variation in the data, they would not be very interesting.

Bubbles must be explosive in the sense that they must grow at a rate that compensates the stock purchaser for the additional amount invested in the stock due to the bubble. In addition, there may be a risk premium to compensate stockholders for the additional risk that the bubble may burst. "This characteristic causes the price to deviate further and further from the fundamentals for as long as the bubble lasts.

Bubbles can not be negative. A negative bubble means that stock prices are less than implied by the fundamentals. The explosive characteristic of bubbles means that the prices implode with some chance that stock prices will be negative at some future date." Negative stock prices, however, are impossible; they are inconsistent with the liability rules associated with common stock which limit potential losses to the extent of the initial investment.

\section{RATIONAL BUBBLES AND STOCK PRICE BEHAVIOR}

The theory of rational bubbles has implications for the behavior of stock prices that are different than the theofy of efficient markets. ${ }^{19}$ This is shown in lable 2, which makes use of the fundamentals theory of stock price determination discussed above. One important assumption of this example is that, at each moment in time, investors expect dividends to grow at a constant rate over the future. To keep things simple, the example assumes that subsequent events conform

\footnotetext{
7See Diba and Grossman (1985 and 1986), Blanchard and Watson (1982), Flood and Garber (1980), West (1986) and the appendix to this paper.

:See Diba and Grossman (1985 and 1986) and Blanchard and Watson (1982)

sSee Diba and Grossman (1985) and the appendix
}

to the expectations of investors iperfect foresight, an extreme version of rational expectations and that the dividend is initially expected to be $\$ 2$. The expected dividend is constant in panel $A$ lexpected growth rate is zero but grows in panel $B$ at an expected annual rate of 2 percent. The required discount rate is 10 percent, and a bubble of $\$ 1$ occurs in period zero.

Column 3 of panel A computes the fundamentals price, $P$. This is simply the expected dividend, $\mathrm{D}_{4}\left(\mathrm{D}_{\mathrm{t}, \mathrm{t}}\right)$ $=\$ 2$, (assumed constant in panel $A$ ) divided by the difference between the required discount rate, $\mathrm{T}=.10$, and the expected growth rate in dividends, $g=0$. The fundamentals price is $\$ 20$ each period.

The fourth column computes the bubble component of the price. As discussed above, the bubble expands over time at the required discount rate, $r$. The observed price, $p_{1}$, is the sum of the fundamentals price and the bubble as in column 5 .

Column 6 calculates the percentage changes in the price. These are positive. More importantly, the numbers in column 6 rise over time indicating that this bubble produces a time series of observed price changes that are positively correlated. The observed price does not follow a random walk. Of course, the real world is never so neat. Changes in the fundamentals -,$g_{,} \mathrm{E}_{4}\left(\mathrm{D}_{4+1}\right)-$ may cause the observed price to change in a way that masks the bubble. If that occurs however, it is not clear that the bubble is very important since an investor's behavior under the theory of rational bubbles depends on his ability to detect the presence of bubbles.

The example in panel $B$ is similar to the example in panel $A$ except that dividends are expected to grow at a 2 percent annual rate. Notice that this does not change the qualitative result with respect to the observed price changes. 'These rise over time and will be positively correlated. The only difference between the two examples is that the fundamentals price in panel $B$ rises (drifts upward) over time at a constant 2 percent rate (see column 7 ). This results from the growth in dividends. While the fundamentals price drifts upward at a constant rate of 2 percent, the sequence of changes in the fundamentals price are uncorrelated. The fundamentals price will follow a random walk with drift

An important thing to note is that both the greater fool theory and the theory of price bubbles discussed in this paper imply that stock prices behave similarly. Both reject the efficient markets hypothesis, which implies that stock prices follow a random walk. 
Table 2

Fundamentals vs. Bubbles: An Example

\begin{tabular}{|c|c|c|c|c|c|c|}
\hline \multicolumn{7}{|c|}{ Panel A Expected growh or divclends to zer } \\
\hline Years & $\mathrm{E}(\mathrm{D}, \mathrm{x})$ & Pro & $\mathrm{g}=1+7+\mathrm{m}$ & $P=P+B$ & (1) & 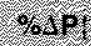 \\
\hline 6 & 9206 & 82000 & 51.00 & 52100 & & \\
\hline 1 & 2.00 & 2000 & 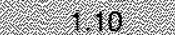 & 27,10 & 48 & $00 \%$ \\
\hline 2 & 200 & 2000 & 1,21 & 27.2 & 52 & 00 \\
\hline te & 2.00 & 26,00 & 1.38 & 21.3 & 57 & ro \\
\hline 4 & 2010 & 20.610 & 146 & 2140 & 61 & 0.0 \\
\hline 6 & 200 & 2010 & 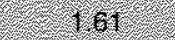 & 2176 & 70 & 0 \\
\hline
\end{tabular}

Panel B. Expected groulh or dividends ts 2 pereeni

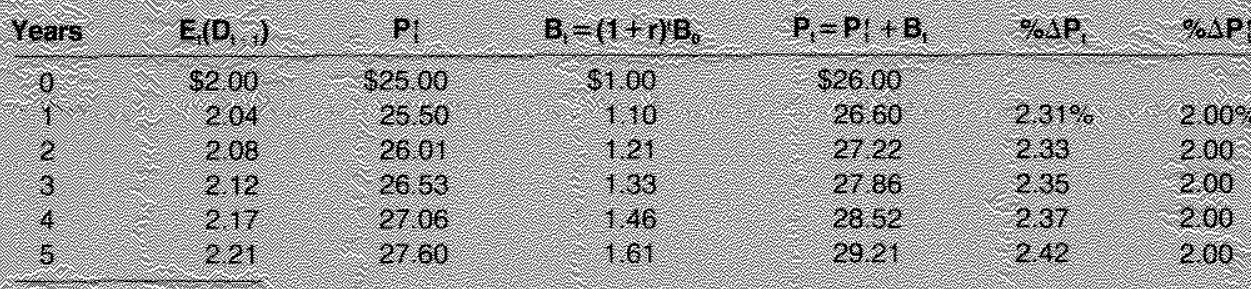

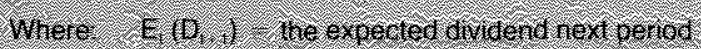

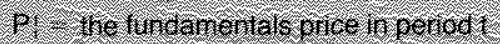

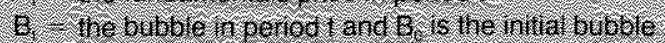

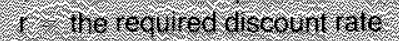

r. the olserved e irein lerod:

9. 1 le expetrer growh are in dividerds

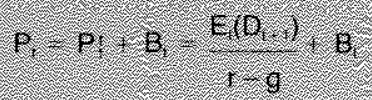

\section{SOME PROBLEMS WTTH BURBLES}

The notion that stock prices are influenced by bubbles is troublesome because if is not based on a well-specified theory. A complete theory of bubbles should identify the cause of bubbles in terms of some phenomenon that can be observed separately from bubbles themselves. On those occasions when the cause is observed, a bubble should also be observed and conversely. This allows a direct test of the theory and explains why bubbles may be observed on some occasions but not others.

In contrast, the greater fool and rational bubble theories do not suggest a cause of bubbles that can be observed separately. Rather, unusual price behavior the bubble is atributed to "intense optimism," "a compulsion to speculate" and "manias." These do not identify the cause of the bubble; they merely give the bubble a different name.:

These criticisms suggest that attributing crashes in stock prices to bursting bubbles adds nothing to our understanding of why crashes occur or how to prevent similar occurences in the future. To illustrate,

20Brumer and Meltzer (1987) note that

Some further feflections on bubbles and surnspots equilibria should make us doubt their contribution to a useful reconciliation of analysis with critical observations. The bubble term refers neither directly hor indirectly to any observable entities. It is fundamentaly inconsistent with any rational exploitation of information invoked by the same analysis ( $p .2)$.

See, as well, Singleton (1987), pp. 28-30. Sirkin (1975) and Schwartz (1981), p. 25, question the bubble hypothesis as an explanation of the 1929 crash. 
Wesley Clair Mitchell a noted student of business cycles/ wrote that

By a combination of various agencies such as public regulation of the prospectuses of new companies, legislation supported by efficient administration against fraudulent promotion, more rigid requirements on the part of stock exchanges concerning the securities admitted to official lists, more efficient agencies for giving investors information, and more conservative policy on the part of the banks toward speculative booms, we have learned to avoid certain of the rashest errors conmitted by earlier generations."

Mitchell made this statement in 1913 in reference to the legislative and regulatory precautions instituted after the Panic of 1907. Like the crash in 1929, the 1907 crash had been attributed to a speculative bubble.

\section{EFFICIENT MARKETS VS. PRICE BUBBLES: SOME EVIDENCE}

The efficient markets hypothesis suggests that stock prices follow a random walk. The hypothesis has no implication for the drift in stock prices. Prices may be higher or lower at the end of the period being examined. Neither of these events is necessarily inconsistent with the hypothesis. Rather, the hypothesis implies that the sequence of price changes are unrelated; they behave as andom variables. In contrast, the greater fool theory and the theory of rational bubbles discussed here imply that changes in stock prices are not random but are positively related. Which explanation is better supported by the evidence for the 1924-29 and 1982-87 bull markets?

To evaluate these theories, data on the level of the Dow Jones Industrial Index are used. Two periods are examined. One extends from January 3,1928 , through September 3,1929 . The second runs from January 2 , 1986, through August 25, 1987. The data are tirst differences of the log of the Dow's daily closing level multiplied by 100 and are approximately equal to the daily percentage change in the index. Each sample contains more than 400 observations. Stock prices advanced very rapidly in these periods. If bubbles were present, they should be apparent in these data.

\section{Were Stock Prices A Random Walk?}

Table 3 presents the results of a test /called a BoxPierce test based on the estimated autocorrelations of percentage changes in the Dow Jones Industrial In-

¿Mitchell (1950). p. 172.

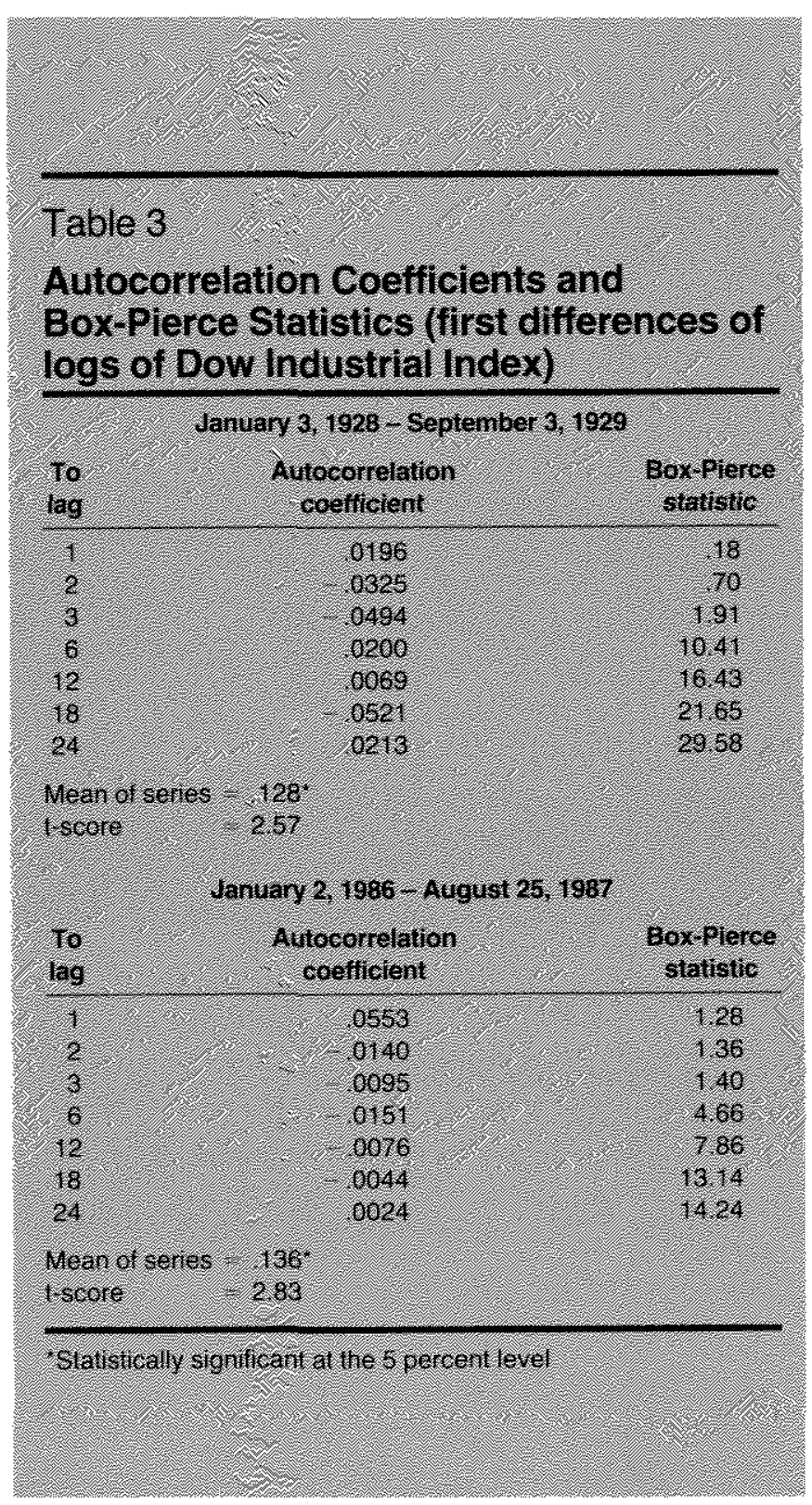

dex. This test is designed to determine whether there is significant autocorrelation in the data, that is, whether current changes in the index are related to past changes. Recall that the efficient markets hypothesis implies that past changes in stock prices are unrelated to (contain no information about) current or future changes. An empirical counterpart of this proposition is that changes in the index are not correlated. Conversely, if the hypothesis that stock prices were influenced by self-feeding bubbles is correct, percentage changes in the index should be positively correlated.

Table 3 shows test results for the two periods discussed above. None of the test statistics indicate signi- 
Chart 2

An Illustration of a Random Sequence Vs. Correlated Observations $\longleftarrow$

Panel A: Random sequence

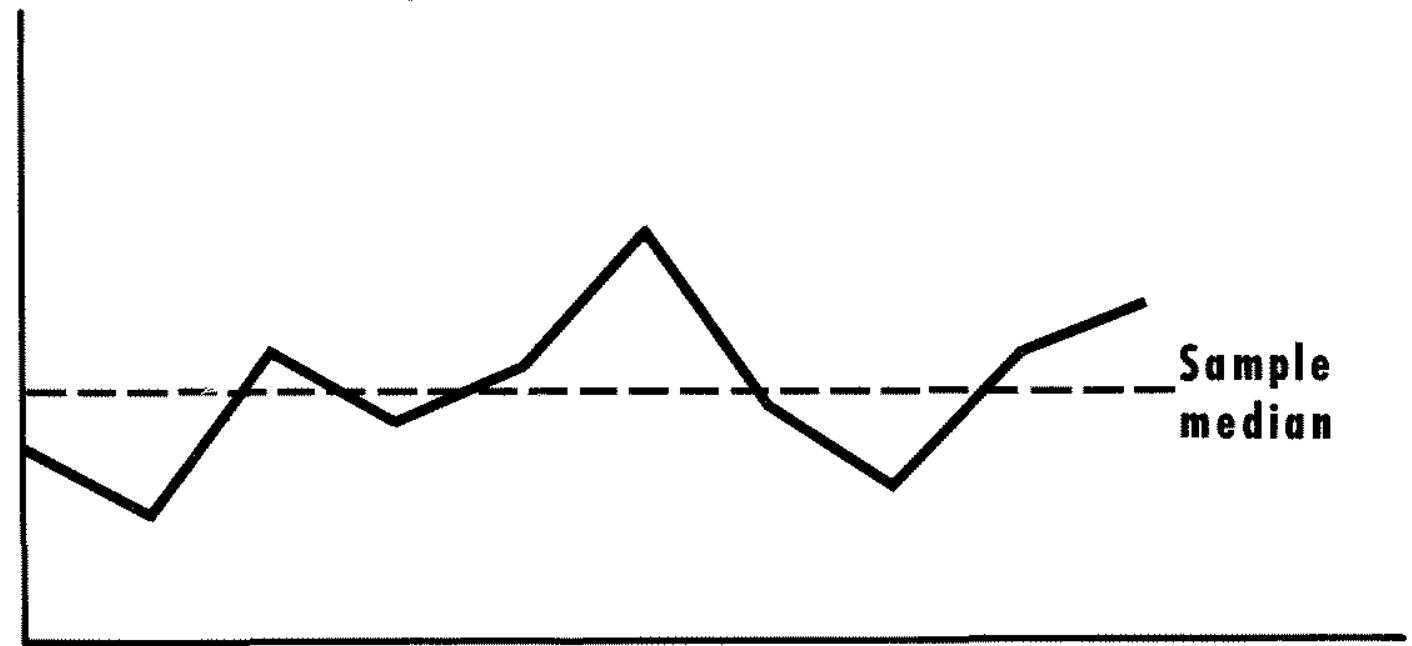

Panel B: Correlated observations

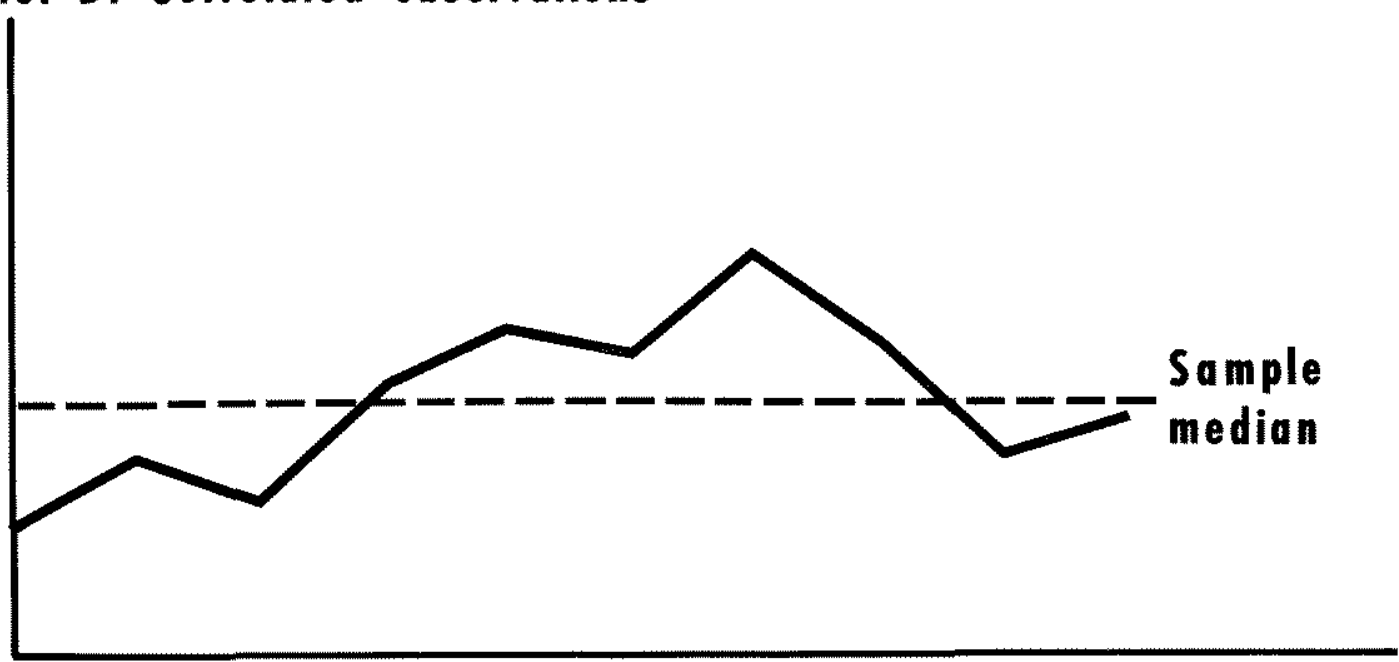

LSee Wonnacott and Wonnacott (1977), p.487. 


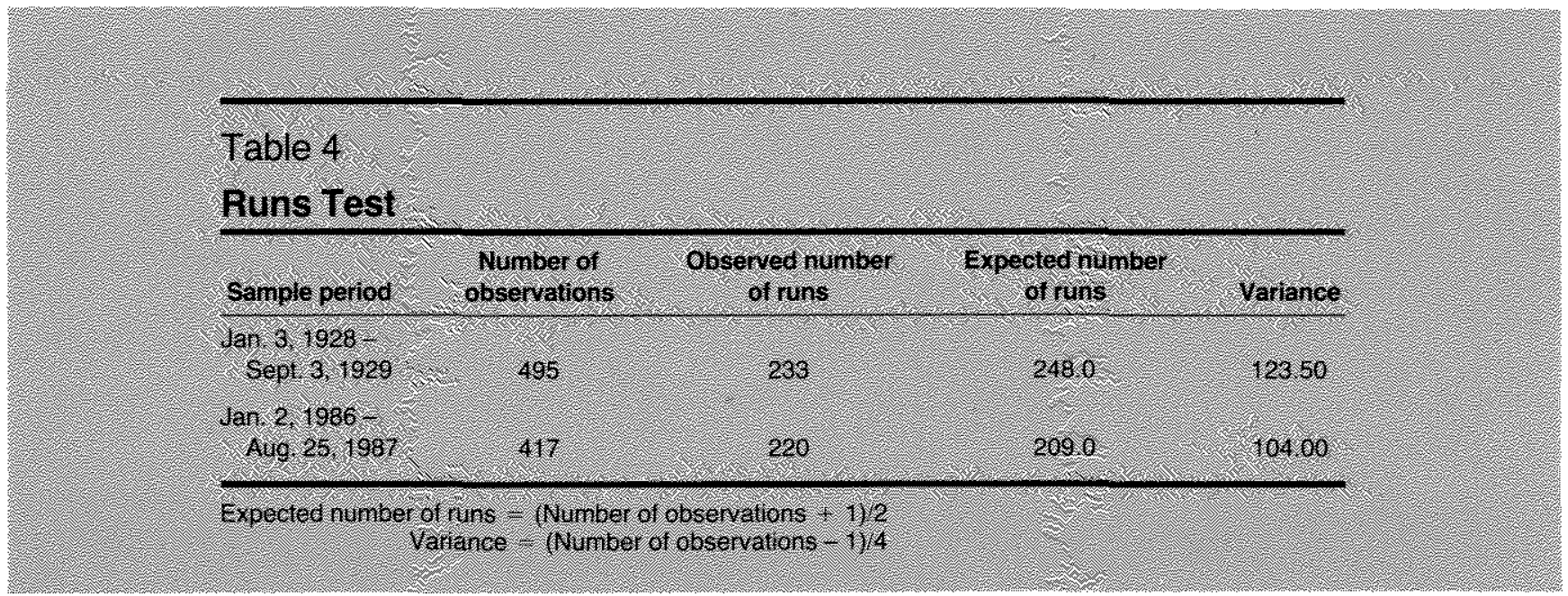

ficant correlation at conventional confidence levels. ${ }^{22}$ Stock prices followed a random walk, which is consistent with the efficient markets hypothesis.

Table 3 also shows the mean change for each period. The means are positive and significantly different from zero in a statistical sense. Today, the upward drift in stock prices during these time periods is obvious. At that time, however, the upward drift is not something that investors could have bet on with any confidence.

\section{Runs Test}

A run is the number of sequential observations that are greater or less than the sample median (the middle value of the samplel. If a series of observations exhibits too few runs relative to what is expected for independent observations, the data are positively correlated or drawn from different populations.

The efficient markets hypothesis suggests that observed changes in stock prices are uncorrelated, that is, the changes are independent of one another. This means, for example, that there is no tendency for a large positive change to be followed by another large positive change. Consequently, the sequence of observed changes will move back and forth across the median change for the sample fairly frequently as shown in panel A of chart 2 . If changes in stock prices

2zDaily data between October 22, 1929, and March 31, 1930, show significant autocorrelation at various lags. This is likely a statistical arifact produced by a substantial increase in the variance of the data at the time of the crash in October and November that appears to taper off over time. Consequently, the significant correlations do not suggest the presence of a bubble. Furthermore, stock prices were declining at this time and bubbles can not be negative. are correlated as implied by the bubble hypothesis, however, a plot of the observations in the order that they appear will indicate some tracking as shown in panel $B$. This plot crosses the sample median infrequently. The example exhibits relatively long and, consequently, fewer runs than expected of independent observations. ${ }^{\text {23 }}$

Table 4 presents the results of a runs test for the bull markets of the 1920s and 1980s. The third column of the table shows the number of runs observed for daily percentage changes in the Dow Jones Industrial Index during each period of rapidly increasing stock prices. Column 4 gives the number of runs expected for a series of 4995 and 417$)$ independent observations and column 5 gives the variance of this series. Since the observed number of runs is not much different than expected, the hypothesis that percentage changes in the Dow Index behaved randomly during the sample periods is not rejected by this data.

The evidence on the behavior of stock prices (as characterized by the Dow Index) is not consistent with the notion that stock prices were driven by selffeeding speculative bubbles during the 1920s and 1980s.

\section{CONGLUSION}

Many people attribute the stock market crashes of 1929 and 1987 to bursting speculative bubbles. The perception that stock prices may be driven by bubbles presents economic policymakers with an important problem because such bubbles suggest that plans to

2aSee Wonnacott and Wonnacott (1977), pp. 486-88. 
save and invest may be based on irrational criteria and subject to eratic behavior.

This paper has examined data on stock prices around the time of the Coolidge and Reagan bull markets. The paper provides evidence contrary to the notion that the crashes were the result of bursting speculative bubbles. No evidence was found that changes in stock prices were autocorrelated or that the data contained long runs. Rather, the data suggest that stock prices followed a random walk. This evidence is consistent with the efficient markets hypoth esis, which is based on the proposition that all relevant and ascertainable information regarding stock price fundamentals interest rates, dividends, future prospects, etc. is contained in current stock prices.

\section{REFERENCES}

"Abreast of the Market." Wall Street Joumal, January 26, 1987.

Blanchard, Oliver J., and Mark W. Watson. "Bubbles, Rational Expectations, and Financial Markets," in Paul Wachtel, ed., Crises in the Economic and Financial Structure (Lexington Books, 1982), pp. 295-315.

Brealey, R. A. An introduction to Risk and Retum from Common Stocks (The MiT Press, 1983).

Brealey, Richard, and Stewart Meyers. Principles of Corporate Finance (McGraw-Hill, 1984).

Brunner, Karl. "Epilogue: Understanding the Great Depression," in Karl Brunner, ed., The Great Depression Revisited (Martinus Nijhoff, 1981), pp. 316-58.

Brunner, Karl, and Allan $\mathrm{H}$. Meltzer. "Bubbles and Other Essays," Carnegie-Pochester Conference Series on Public Policy (Spring 1987), op. 1-8.

Cowles, Afred III, and Associates. Common-Stock Indexes, 1871 1937 (Principia Press, 1938)

Diba, Behzad T., and Herschel I. Grossmar. "Rational Bubbles in Stock Prices?" (National Bureau of Economic Research, Working Paper 1779,1985$)$

"On the Inception of Rational Bubbles in Stock Prices." (National Bureau of Economic Research, Working Paper 1990. 1986).

Fama, Eugene F. "Efficient Capital Markets: A Review of Theory and Empirica Work," Joumal of Finance Papers and Proceedings (May 1970), pp. 383-417.

Flood, Robert P., and Peter M. Garber. "Bubbles, Runs, and Gold Monetization," in Paul Wachtel, ed., Crises in the Economic and Financial Structure (Lexington Books, 1982), pp. 275-93.

"Market Fundamentals versus Price-Level Bubbles: The First Tests," Journal of Political Economy (August 1980), pp. $745-70$.

Friedman, Milton, and Anna d. Schwartz. Monetary Trends in the United States and United Kingdom, 1867-1975 (Chicago University Press, 1982).

A Monetary History of the United States, 1867-1960 (Princeton University Press, 1963).

Galbraith, John Kenneth. The Great Crash (Houghton Miffin, 1955).

Gordon, Robert A. Business Fuctuations (Harper and Brothers, 1952).
Hodson. H. V. Economics of a Changing World (Harrison Smith and Rober Haas, 1933), p. 164

Homer, Sidney. A History of Interest Rates (Rutgers University Press, 1977).

Jonas, Norman, and Christopher Farrell. "Program Trading: Let the Little Guy In," Business Week (Seplember 29, 1986), p. 100.

Keynes, John Maynard. The General Theory of Employment, Interest and Money (Harcourt, Brace and Company, 1935).

Kindleberger, Charles P. Manias, Panics and Crashes (Basic Books, 1978).

Koepp, Stephen. "How Ripe for a Crash?" Time (October 5, 1987), pp. 44-46.

Leroy, Stephen F. "Expectations Models of Asset Prices: A Survey of Theory," Journal of Finance (March 1982), pp. 185-217.

Makkiel, Burton G. A Random Wakk Down Wall Street (W. W. Norton and Company. 1981).

Mankiw, N. Gregory, David Romer, and Mathew D. Shapiro. "An Unbiased Reexamination of Stock Market Volatility," doumal of Finance (July 1985), pp. 677-87.

Mitchell, Wesley Clair. Business Cycles and Their Causes (University of California Press, 1950).

Moore, Geoffrey $H$. Business Cycle Indicators, vol. 2 (Princeton University Press, 1961).

New York Times (September 6, October 24, and 25, 1929).

Niebuhr, Reinhold. "The Speculation Mania," The World of Tomorrow (January 1930 ), pp. 25-27.

Patterson, Robert T. The Great Boom and Panic (Henry Regnery Company, 1965).

Peters, William S. and George W. Summers. Statistical Analysis for Business Decisions (Prentice Hall, Inc., 1968)

Powell, Bill. "The Prophets of Gloom '87," Newsweek (Seplember $14,1987)$, p. 56.

Pierce, Phyllis S. The Dow Jones Averages 1885-1980 (Dow JonesInwin, 1982)

Roepke, William. Crises and Cycles (Wiltiam Hodge and Company Ltd., 1936$)$, pp. $51-52$

Schumpeter, Joseph A. Business Cycles (McGrawnHil, 1939), vol. 2

Schwartz, Anna J. "Understanding 1929-1933" in Karl Brunner, ed., The Great Depression Fevisited (Martinus Nijhoff ${ }_{3}$ 1981), pp. $5-48$.

Schwartz, John, and Dody Tsiantar. "The Market's Latest Bull Run," Newsweek (August 24, 1987), p. 32.

Shiller, Robert J. "Do Stock Prices Move Too Much to be Justified by Subsequent Changes in Dividends?" American Economic Review (June 1981), pp. $421-36$.

Singleton, Kenneth. "Speculation and the Volatility of Foreign Currency Exchange Rates," Camegie-Rochester Conference Series on Public Policy (Spring 1987), pp. 9-56.

Sirkin, Gerald. "The Stock Market of 1929 Revisited: A Note," Business History Review (Summer, 1975), pp. 223-31.

Snyder, Carl. Capitalism the Creator (The Macmillan Company, 1940), p. 229.

Sparling, Earl. Mystery Men of Wall Street (Blue Ribbon Books, 1930).

Varian, Hal R. "Catastrophe Theory and the Business Cycle," Eco" nomic inquiry (January 1979), pp. 14-28.

Wall Street Journal. October 26, 1987. 
Wanniski, Jude. The Way the World Works (Basic Books, 1978), pp. 116-48.

West, Kenneth D. "Dividend Innovations and Stock Price Volatility," Discussion Paper \#113 (Princeton University Working Paper, July 1986).
Willis, Parker H. "Who Caused the Panic of 1929?" North American Review (February 1930), p. 183.

Wonnacott, Thomas H., and Ronald J. Wonnacott. Introductory Statistics for Business and Economics (John Wiley and Sons, $1977)$ 


\section{Appendix Price Bubbles}

The following assumes rational investors with infinite time horizons and a complete set of markets. With these assumptions, the solution for the expected price of a share of stock next period given the information set in $t$, $E_{t}\left(P_{i: 1} \mid W_{1}\right)_{s}$ is its price this period, $P_{1}$ plus appreciation during the period at the market rate of discount, $r_{z}, P_{t}$, less the expected dividend in $t+1, E_{1}\left(X_{1+3} \mid w_{t}\right)^{t}$ This relationship is summarized in equation 1.

(1) $\mathrm{E}_{1}\left\{\mathbf{P}_{1+1} \mid \mathrm{w}_{1}\right\}=\mathbf{P}_{1}+\mathbf{r}_{1} \mathbf{P}_{1}-\mathrm{E}_{1}\left\{\mathrm{X}_{t+1} \mid \mathrm{w}_{1}\right\}$

The fundamentals price is the discounted present value of the expected future stream of dividends. This is shown in equation 2 for the price in period $t^{2}$ Note that $r_{i}$ is the $i^{\text {th }}$ period interest rate.

$$
\text { (2) } \begin{aligned}
P_{t} & =\sum_{i=1}^{\infty} \theta_{i} E_{t}\left(X_{i+j} \mid w\right) \\
\theta_{i} & \left.=1 / 1+r_{i}\right\}^{j}<1
\end{aligned}
$$

If the expected dividend receipt is the same in each future period, $\left.\mathrm{E}_{t}\left|\mathrm{X}_{t+1}\right| \mathrm{w}_{t}\right\}=\mathrm{E}_{1}\left(\mathrm{X}_{t+1} \mid \mathrm{w}_{1}\right)$ for all $\mathrm{i}$; and the yield curve is flat so that $r_{t}=F_{\text {; }}$ for all $i$, equation 2 can be rewritten in the following form.

(3) $P_{t}=E_{t}\left(X_{1+1} \mid w_{1}\right) / r_{1}^{2}$.

Substituting (3) into 1 and collecting terms gives the solution that the expected price in period $t+1$ is the price in period $t$

$$
\mathrm{E}_{\mathrm{q}}\left(\mathbf{P}_{\mathrm{t}+1,1} \mid \mathbf{w}_{\mathrm{g}}^{\mathrm{j}}=\mathbf{P}_{\mathrm{q}}\right.
$$

The observed price in $t+1$ can be expressed as the period 1 expectation of the price in $t+1$ lwhich, by the above angument, is equal to $P_{3}$, and a white noise error term, $\epsilon_{1+1}$, as in equation 4.

(4) $P_{1+1}=P_{q}+E_{1+1}$

Equation 4 is consistent with the efficient markets solution for asset prices. It implies that prices follow a random walk.

'See Brealey and Meyers (1984), pp. 45-47, and Blanchard and Watson (1982), pp. 296-97.

2See Shiller (1981), Blanchard and Watson (1982), West (1986) and Mankiw, Romer and Shapiro (1985).

${ }^{3}$ The data are consistent with this assumption during the period analyzed in the shaded insert on page 21. For example, the average difference between the yield on high-grade corporate bonds and the call money rate was -30 basis points, which is not significantly different from zero ( $t$-score $=, 74$ ). Furthermore, the data are consistent with the assumption regarding expected dividends. It is not possible to relect the hypothesis that dividends per share followed a random walk. The first differences of dividends per share are a white noise process. The Box-Pierce statistics al lags $6,12,18$ and 24 are $6.94,12.33,14.10$ and 17.47. The dividend data are from cowles (1938). The data are annual for the period 1871-1930.
The notion iexpressed by Sen. King and others that the Coolidge market was the product of a price bubbe that eventually burst is approximated by a theory that allows share prices to deviate from the fundamentals price in period $t$ by bubble, $B_{3}$ with probability $\pi$. The average duration of the bubble is $1 / 1-\pi$ ) periods before it crashes. Given the assumptions reganding expected future dividends and the shape of the yield curve, a solution for the price that allows for bubbles. $P_{1}^{\prime}$, is:

$$
\text { (5) } \begin{aligned}
\mathrm{P}_{1}^{\prime} & =\mathrm{E}_{\mathrm{t}} \mathrm{X}_{1+1} \mid \phi_{1} \mathrm{l}_{\mathrm{t}}+\mathrm{B}_{\mathrm{t}} \\
\mathrm{B}_{\mathrm{t}} & =\pi \Theta^{-1} \mathrm{~B}_{\mathrm{t}-\mathrm{t}}+\mathrm{U}_{4} \text { with probability } \pi \\
\mathrm{B}_{1} & =\mathrm{U}_{1} \text { with probability } 1-\pi \\
\mathrm{E}_{4}\left(\mathrm{U}_{1} \mid \phi_{1-1}\right) & =0 .
\end{aligned}
$$

Substituting $(5)$ into $(1)$ and collecting terms gives the solution that the expected price of a share next period is its price this period plus the appreciation in price due to the period t bubble.

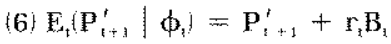

As long as the bubble lasts, the actual rate of return from holding the stock exceeds the market rate of discount, $r$. This compensates for the risk of a crash in the share price should the bubble burst.

The price in $t+1$ is the sum of the expected price and at while-noise error lerm.

$(\gamma) P_{t+1}^{r}=E_{t}\left(P_{1+1} \mid \phi_{1}\right)+\epsilon_{\mathrm{g}}=P_{1}^{r}+r_{1} B_{1}+\epsilon$

(8) $\mathrm{E}_{\mathrm{t}}\left(\mathbf{P}_{\mathrm{\varepsilon}+1}^{\prime}-\mathrm{P}_{\vdots}^{\prime}\right)=r_{1} \mathrm{~B}_{\mathrm{\varepsilon}}=r_{1} \pi \theta^{-1} \mathrm{~B}_{\mathrm{l}-1}>0$

Notice that the expected change grows over time at rate so the market price is expected to deviate further from the fundamentals price in each subsequent period for as long as the bubble lasts.

Furthermore, as shown below, the expected percentage change in the price is nol constant.

(9) $\mathrm{E}_{\mathrm{t}}\left[\left(\mathbf{P}_{1+1}^{\prime}-\mathbf{P}_{\mathrm{t}}^{\prime}\right] / \mathbf{P}_{1}^{\prime}\right]=\Gamma_{\mathrm{l}} \mathbf{B}_{\mathrm{t}} / \mathbf{P}_{1}^{\prime}$

Substituting for $\mathrm{p}^{\prime}$ from 5 ! and noting that the fundamentals price, $\mathbf{P}_{1}^{\prime}=\mathrm{E}_{3}\left(\mathrm{X}_{\mathrm{t}, \mathrm{x}} \mid \phi_{\mathrm{i}} \mathrm{j} / \mathrm{r}_{\mathrm{z}}\right.$, gives

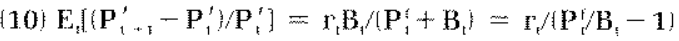

Since $B$, grows at mate $r$, the percentage change in ptice is expected to rise over time.

In contrast to the efficient markets solution, bubbles imply that share prices do not exhibit random wak properties.

¿See Blanchard and Watson (1982), pp. 297-98. 